\title{
The efficacy of lindane and dimethoate against cabbage maggots in Finland
}

\author{
Anna-LiIsa Varis and Pirjo Dalman ${ }^{1}$ ) \\ University of Helsinki, Department of Agricultural and Forest Zoology, Viikki, \\ SF-00710 Helsinki 71, Finland.
}

\begin{abstract}
Various rates of lindane and dimethoate were used in different localities against cabbage maggots in cabbages and tests were done on hatching larvae of Delia floralis Fall. to determine the possible resistance of 3 field strains to these insecticides. Considerable differences were noted in the efficacy of both insecticides in various localities and significant differences were found in the susceptibility of different strains to both insecticides. The LC 50-values compared with those of the most susceptible strain were, however, less than 3 -fold. The reasons for the poor efficacy of the insecticides are discussed.
\end{abstract}

\section{Introduction}

Since the early 1960's several reports have been published on the resistance of cabbage root fly, Delia brassicae Bouche, against chlorinated hydrocarbon and organic phosphate insecticides (e.g. HowitT and Cole 1962, CoAKer et al. 1963, Hellovist 1968, Henneguin and Auge 1975). Reports concerning resistance of the turnip root fly Delia floralis ar considerably fewer owing to the fact that $D$. floralis is univoltine while $D$. brassicae usually has more than one generation in the area where it occurs. TAKSDAL (1966) found that $D$. floralis had become resistant against lindane and aldrin in northern Norway. According to Stewart and McKinlay (1965) the third larval instar of $D$. floralis showed increased tolerance to heptachlor in the laboratory.

Because repeated claims have been made by the growers on the weakened effect of the insecticides against root maggots on cruciferous crops in Finland, investigations on the possible resistance to the insecticides generally used for this purpose were carried out in 1976. This paper reports on the results of these studies.

1) Present address: Agricultural Research Centre, South Savo Experimental Station, SF-50600 Mikkeli 60, Finland. 


\section{Materials and methods}

A question naire was sent to cabbage growers through the vegetable growing advisers of the Agricultural Centres in order to find out the possible resistant strains of cabbage root flies in Finland. 37 replies were received totalling up to 166 ha which is about $20 \%$ of the cabbage growing area of the country. The smallest cabbage growing area represented was 11 a and the largest 30 ha, the mean size being 4.5 ha.

Fie ld t rials were carried out on some farms where, according to the questionnaire, previously successful root maggot control after a long use in the preceding years had failed and for comparison also in places where the effect of the insecticides had continued to be normal, and on the use of insecticides of shorter duration.

The plants grown in seedbed under glass were treated with insecticides after being planted in the field. In lindane treatments $0.46 \%$ fine granulate (Agrocide 2) was mixed with the soil surface around the plant at rates given in Table 1. Dimethoate, $40 \%$ emulsion (Roxion) in dilutions of $0.02,0.04$ and $0.08 \%$, was used as soil drench at the bases of the plants (Table 1). The dead plants were examined for root maggot damage during the growing season. In connection with the harvest every plant was checked for root maggot damage using a scale $\mathbf{0 - 5}$ (completely healthy-totally destroyed).

Testing for resistance. The larval test method described by READ (1965) for D. brassicae and modified by Nedstam (1974) was used. The testing time had, however, to be lengthened for D. floralis. The test insects were collected as larvae from the fields where the effect of insecticides was poor and for comparison from places where it was moderate. They were put in plastic pots $\varnothing 22 \mathrm{~cm}$ filled with wet turf and kept in $20-23^{\circ} \mathrm{C}$. Pieces of swedes were placed in the pots and added to when necessary. When all the larvae had pupated each pot was covered with a PVC rearing cylinder $37 \mathrm{~cm}$ high. The emerged flies, (1 349 specimens in all), were collected and identified daily. They were put in rearing cages $60 \mathrm{~cm}$ high and $30 \mathrm{~cm}$ square, $100-150$ flies in each cage with equal numbers of males and females. A wet turf layer was placed on the bottom of the cages to preserve the moisture. A soyamealyeast mixture 7: 3 added with water was given for food. Sugar and fresh dandelion flowers were also available in each cage.

A week after the emerging of the flies the cages were provided with small glass vials with moist fine sand and a slice of swede for egg laying. The eggs were removed every second day with the sand layer and put in a glass vial filled with water which was stirred with a glass stick and sieved on a piece of dark cloth and used for testing 2.9.-3.10. A total of $6200 \mathrm{D}$. floralis eggs was $€$ xamined. The insecticides used were lindane (Silvanol) and dimethoate (Roxion) in concentrations of $0.00125,0.0025,0.005,0.01,0.02,0.04,0.08,0.16$, 0.32 and $0.64 \%$ active ingredient. The strains selected and tested on the base of field trials (locations in Fig. 1.) were: strains $\mathrm{O}$ (Oulu) and V (Vantaa) for lindane resistance and strains $\mathrm{O}$ and $\mathrm{H}$ (Haukivuori) for dimethoate resistance. Strain $\mathrm{K}$ (Kangasala) was used as a standard because of adequate control in the field trial with both insecticides combined with a relatively short use of insecticides and with no complaints over any reduced effect from the grower. 


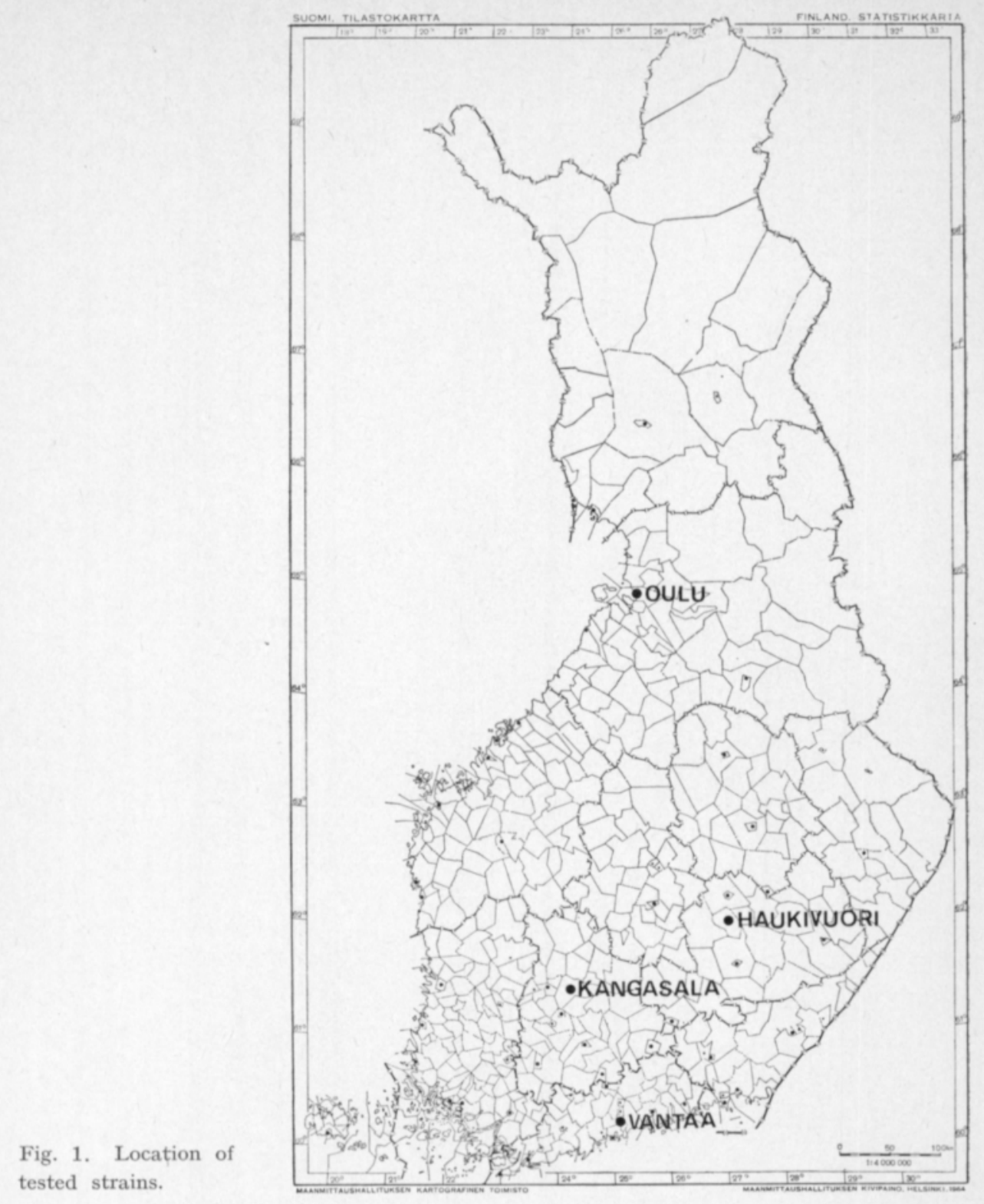

\section{Results}

The most general insecticide for cabbage maggot control was dimethoate, which was used on more than $2 / 3$ of the cabbage growing area. Next in order was lindane followed by diazinon and trichloronate. Bromophos, parathion and malathion were also used to a minor extent.

Ten growers out of 37 considered the effect of insecticides not as good as in previous years.

In field trials the damage was very heavy in Oulu, where also the efficacy of both insecticides was poor (Table 1). In Haukivuori the efficacy of dimethoate was rather poor but that of lindane considerably better. In Kangasala and Vantaa there was less damage and the effect of both insecticides was moderate. 
The highest dimethoate concentration 0.08 was phytotoxic causing marginal chlorosis. This phytotoxicity was also to be seen in the yield results in some places. In all field trials $D$. floralis was the dominant species (Table 2).

Table 1. Damage by root maggots after various treatments at different localities

\begin{tabular}{|c|c|c|c|c|c|}
\hline \multirow{2}{*}{ Insecticide } & \multirow{2}{*}{$\begin{array}{c}\text { AI } \\
\text { g/plant }\end{array}$} & \multicolumn{4}{|c|}{ Damage $(0-5)$} \\
\hline & & Vantaa & Kangasala & Haukivuori & Oulu \\
\hline \multirow[t]{3}{*}{ Lindane } & 0.0046 & 1.2 & 0.9 & 1.7 & 4.3 \\
\hline & 0.0092 & 0.7 & 0.3 & 1.5 & 4.7 \\
\hline & 0.0184 & 0.8 & 0.3 & 1.4 & 4.2 \\
\hline \multirow[t]{3}{*}{ Dimethoate } & 0.01 & 1.7 & 0.9 & 2.9 & 4.6 \\
\hline & 0.02 & 0.7 & 0.6 & 2.6 & 3.6 \\
\hline & 0.04 & 0.3 & 0.3 & 1.6 & 3.7 \\
\hline Untreated ..................... & & 2.1 & 1.3 & 3.3 & 4.9 \\
\hline
\end{tabular}

Table 2. The occurrence of Delia brassicae and D. floralis on cabbages at different field trial localitie 3

\begin{tabular}{|c|c|c|c|c|}
\hline & $\begin{array}{c}\text { Delia brassicae } \\
\%\end{array}$ & $\begin{array}{c}\text { Delia floralis } \\
\%\end{array}$ & $\begin{array}{c}\text { Other species } \\
\%\end{array}$ & Total number \\
\hline 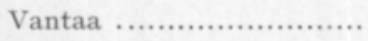 & 1.6 & 95.2 & 3.2 & 250 \\
\hline Kangasala ..................... & 0 & 100 & 0. & 285 \\
\hline Haukivuori .................... & 1.4 & 982 & 0.4 & 441 \\
\hline \multirow[t]{2}{*}{ 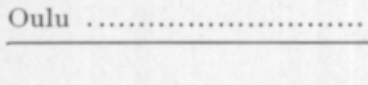 } & 0.3 & 82.8 & 16.9 & 373 \\
\hline & & & & 1349 \\
\hline
\end{tabular}

When lindane was used in resistance testing at the concentration recommended for growers, $0.04 \%$, the mortality of different strains varied from 73.6 (V) to $98.7 \%(\mathrm{~K})$. In the K-strain the LC 50 was significantly lower than in other strains (Table 3 ) between which no significant differences were noted. The resistance coefficients compared with that of the $\mathrm{K}$-strain were as follows: O 2.5, H 2.7 and V 2.9. The regression coefficient in the K-strain was significantly higher than in the $\mathrm{O}$ and $\mathrm{H}$ strains.

When dimethoate was used at the concentration recommended for growers, $0.04 \%$, the mortality was high in each strain varying from 95.6 (V) to $100 \%$ (O). In the K-strain the LC 50 was significantly lower than in other strains and in the O-strain significantly higher (Table 3 ). The resistance coefficients compared with those of the K-strain were as follows: O 2.9, H 1.6 and V 1.5. The regression coefficient in the O-strain was significantly higher than in the other strains. 
Table 3. Regression coefficients (b) and LC50-values of different Delia floralis strains to lindane and dimethoate

\begin{tabular}{|c|c|c|c|c|c|c|}
\hline Insecticide & Strain & b & $\mathrm{s}_{\mathrm{b}}$ & $\mathrm{LC}_{50}$ & \pm & $t_{95 \%}$ \\
\hline \multirow[t]{4}{*}{ Lindane } & V & 1.208 & 0.1615 & 0.0068 & & 0.00119 \\
\hline & K & 1.501 & 0.1710 & 0.0023 & & 0.00035 \\
\hline & $\mathrm{H}$ & 1.231 & 0.0897 & 0.0064 & & 0.00054 \\
\hline & $\mathrm{O}$ & 1.176 & 0.0982 & 0.0057 & & 0.00062 \\
\hline \multirow[t]{4}{*}{ Dimethoate ........... } & V & 1.518 & 0.1755 & 0.0030 & & 0.00042 \\
\hline & K & 1237 & 01253 & 0.0020 & & 0.00030 \\
\hline & $\mathrm{H}$ & 1.386 & 01163 & 0.0033 & & 0.00032 \\
\hline & $\mathrm{O}$ & 2.018 & 02148 & 0.0060 & & 0.00049 \\
\hline
\end{tabular}

\section{Discussion}

Cabbage maggots have been subjected to lindane in Finland for more than 25 years and to dimethoate for about 10 years. In the 1970's the use of dimethoate has increased so that it is now the most common insecticide used for this purpose. According to the inquiry made in connection with this study, dimethoate is estimated to be used in about $2 / 3$ of the cabbage growing area of the country, which is c. 900 ha. Lindane is still used in about $1 / 5$ of the cabbage area, especially in northern Finland.

In Finland both D. brassicae and D. floralis are common, but proportions of the species vary. In 1951-1961 when larvae and pupae of Delia species were collected in different parts of the country, D. brassicae was found to be the most common species (VARIS 1965). In the material collected for the present study, however, the proportion of this species was minute, D. floralis being responsible for practically all the damage. D. brassicae has two generations per year in southern Finland, D. floralis is univoltine. In northern Finland both species occur in one generation. If the treatment is given to the first generation of $D$. brassicae, as recommended in practice, it can not be expected to be effective against $D$. floralis in southern Finland where the latter species occurs about one month later. At that time the root systems of cabbage plants are, however, usually strong enough to withstand the damage. This is not the case in northern Finland where the attack of root flies is often very heavy and severe damage may occur. The difference between the occurrence times of these two species grows smaller towards the north (VARIs 1967) and thus the occurrence of $D$. floralis is there relatively earlier, but late enough for the early treatment. The effect of insecticides was poorest in Oulu, the northernmost place of the study where the damage was so heavy that without treatment practically no yield would have been obtained. The severity of the damage was considered normal by the growers, and in some localities even somewhat slighter than normal. This was also the case according to MARKKULA (1977).

Although the K-strain was most susceptible to both insecticides, the 2-3fold differences in the LC 50 between it and other strains may not be explained as resistance (GEORghiou 1972). In the tests of READ (1965) and NEDSTAM (1974), made by the same method, the differences between susceptible and 
resistant strains of $D$. brassicae against dieldrin were up to 1000 -fold. The low level of resistance may, however, be evidence of a latent period needed before the higher levels of specific resistance are developed, as pointed out by BRown (1971). Especially in northern Finland the refusal of insecticides has lead to increasing rates in applications by the growers. The selection pressure in terms of per cent mortality has, however, not been high from the very beginning and the broadcasting of insecticide which according to COAKER et al. (1963) especially contributes to the developing of resistance, is generally not used. The increased use of incecticides will, however, have contributed to a reduction of natural enemies and thus to increased damage. In England sublethal aldrin and dieldrin residues reduced the numbers of natural enemies and, therefore, increased the attack by D. brassicae (COAKER 1965). Different soils and moisture contents also affect the efficacy of insecticides. (e.g. HARRIS 1964). In the present study the soil was mineral soil in all localities.

\section{REFERENCES}

Brown, A. W. A. 1971. Pest resistance to pesticides. In: White-Stevens, R. (ed.), Pesticides in the environment 1, 2:457-552. New York.

COAKER, T. H. 1965. The effect of soil insecticides on the natural balance of the cabbage root fly (Erioischia brassicae Bouche). XIIth Intern. Congr. Ent. Proc. London 1964, p. 590 .

- , Mowat, D. J. \& Wheatley, G. A. 1963. Insecticide resistance in cabbage root fly in Britain. Nature 200: 664-665.

Georghiov, G. P. 1972. The evolution of resistance to pesticides. Ann. Rev. Ecol. System 3: $133-168$.

HARRIS, C. R. 1964. Influence of soil type and soil moisture on the toxicity of insecticides in soils to insects. Nature 202: 724 .

HeLlogvist, H. 1968. Om resistenta kålflugor. Växtskyddsnot. 32: 90-94.

Hennequin, J. \& Auge, D. 1975. Appréciation des niveaux de résistance de la mouche du chou (Hylemyia brassicae Bouché) aux insecticides organochlorés et organophosphorés. Phytiatrie Phytopharmacie 24: 15-23.

Howitr, A. J. \& Cole, C. G. 1962. Chemical control of Hylemya brassicae (Bouché) in the Pacific Northwest. J. Econ. Ent. 55: 33-38.

MarkкULA, M. 1977. Viljelykasvien tuhoeläimet 1976. Koetoim. ja Käyt. 34:13.

NedstaM, B. 1974. Laboratoriemetod for att undersöka kålfluglarvers resistens mot bekämpningsmedel. Växtskyddsnot. 38: 18-20.

READ, D. C. 1965. Methods of testing Hylemya root maggots for insecticide resistance. J. Econ. Ent. 58: 719-727.

Stewart, W. W. A. \& McKinlay, K. S. 1965. Dissimilarity of heptachlor-resistance in lifestages of the turnip maggot, Hylemya floralis (Fall.) (Diptera; Anthomycidae). Can. Ent. 97: $1166-1170$.

TAKsDal, G. 1966. The turnip root fly, Hylemya floralis (Fallen), resistant to chlorinated hydrocarbon insecticides in Rana, Northern Norway. Acta Agric. Scand. 16: 129-134.

VARIs, A.-L. 1965. Kaalikärpäsen (Hylemyia brassicae Bouché) ja ison kaalikärpäsen (Hylemyia floralis Fall.) elintavoista ja esiintymisestä Suomessa. Mimeogr. 81 p. Helsinki.

- 1967. Studies on the biology of the cabbage root fly (Hylemya brassicae Bouché) and the turnip root fly (Hylemya floralis Fall.). Ann. Agric. Fenn. 6:1-13.

Ms received August 27, 1979. 


\title{
Lindaanin ja dimetoaatin teho kaalikärpäsiin Suomessa
}

\author{
Anna-Lissa Varis ja Pirjo Dalman ${ }^{1}$ ) \\ Helsingin yliopiston maatalous- ja metsäeläintieteen laitos, 00710 Helsinki 71
}

Ristikukkaiskasvien juuria vioittavat kaalikärpäset ovat useissa maissa kehittyneet torjunta-aineita kestäviksi. Kun myös meillä viljelijät ovat valittaneet aineiden tehon heikentyneen, pyrittiin tässä tutkimuksessa selvittämään johtuuko torjunnan vaikeutuminen kaalikärpästen torjunta-aineen kestävyydestä.

Torjuntaa koskevat tiedot saatiin 37 kaaliviljelmältä, joiden viljelyala oli yhteensä 166 ha. Yleisimmin kaalikärpäsiä torjuttiin dimetoaatilla, jota käytettiin kahdella kolmasosalla viljelyalasta sekä lindaanilla, jota käytettiin yhdellä viidesosalla viljelyalasta. Kymmenen viljelijää kolmestakymmenestäseitsemästä ilmoitti torjunta-aineiden tehon heikentyneen.

Kenttäkokeissa tutkittiin dimetoaatin ja lindaanin tehoa Vantaalla, Kangasalla, Haukivuorella ja Oulussa. Kaalikärpäsvioitusta oli eniten Oulussa, jossa molemmat insektisidit tehosivat huonosti. Haukivuorella dimetoaatin teho oli heikko, mutta lindaani tehosi dimetoaattia paremmin. Kangasalla ja Vantaalla vioitusta oli vähän ja insektisidien teho hyvä. $0.2 \%: n$ dimetoaatti aiheutti useissa koepaikoissa kasvien vioittumista. - Juuria vioittaneet kärpästoukat olivat lähes yksinomaan isoa kaalikärpästä, Delia floralis. D. floralis-kantojen dimetoaatin ja lindaanin kestävyys tutkittiin laboratoriossa saattamalla kaalikärpästen munat kosketukseen eri väkevyisten torjunta-aineliuosten kanssa ja laskemalla kuoriutuvien toukkien määrä. Vertailukohteena oli Kangasalan kanta. Sekä dimetoaattia että lindaania käytettäessä vertailukannan LC50-arvo oli merkitsevästi alempi kuin muiden kantojen. Resistenssikertoimet Kangasalan kantaan verrattuna olivat kuitenkin vain $1.5-2.9$, mitä ei vielä voida pitäă osoituksena resistenssin kehittymisestä.

1) Nykyinen osoite: Etelä-Savon koeasema Karila, 50600 Mikkeli 60. 